\title{
Single-stage treatment with ERCP and laparoscopic cholecystectomy versus two-stage treatment with ERCP followed by laparoscopic cholecystectomy within six to eight weeks: a retrospective study
}

Bahtiyar Muhammedoğlu ${ }^{1}$

${ }^{1}$ Clinic of General Surgery, Necip Fazil City Hospital, Kahramanmaras, Turkey

\section{ABSTRACT}

Objective: Obstructive jaundice is one of the earliest symptoms of a hepatobiliary system disorder. The aim of the present study was to compare single stage endoscopic retrograde cholangiopancreatography (ERCP)/laparoscopic cholecystectomy (LC) and two-stage ERCP and LC with respect to the frequency of imaging, duration of anesthesia and the length of stay in our clinic.

Material and Methods: Of the 350 patients undergoing ERCP between 01.01.2015 and 31.12.2016, 31 patients with single-stage ERCP and LC were assigned to Group A and 25 patients with two-stage ERCP followed by LC within 6-8 weeks were assigned to Group B. Eligibility criteria included ERCP duration, difficulty of the procedure, bile duct stones as demonstrated by imaging methods, no contraindications for LC and no suspected or known malignancy. The same surgeon performed ERCP and LC in both groups.

Results: No cases of morbidity or mortality occurred in any groups. The average length of stay was $8.03 \pm 4.97$ days in Group A, which was significantly longer (9.92 \pm 4.05 days) in Group B ( $p<0.026)$. However, the length of stay (in days) was calculated as the time from presentation to hospital until discharge and not the time elapsed after the procedure. Imaging methods were used $3.9 \pm 3.07$ times in Group A and significantly more frequently (5.92 \pm 2.55 times) in Group B ( $p<0.001$ ). Total duration of anesthesia was not statistically significantly different between the study groups (154.06 \pm 53.76 min in Group A and $167.04 \pm 75.17$ min in Group B).

Conclusion: In conclusion, single-stage ERCP/LC is associated with shorter hospital stay and lower frequency of imaging and can be safely used in selected cases. No cases of pancreatitis or mortality occurred following the single-stage procedure. The single-stage procedure can be safely used in selected patients with obstructive jaundice.

Keywords: Endoscopic retrograde cholangiopancreatography, laparoscopic cholecystectomy, magnetic resonance cholangiopancreatography, ultrasonography

Cite this article as: Muhammedoğlu B. Single-stage treatment with ERCP and laparoscopic cholecystectomy versus two-stage treatment with ERCP followed by laparoscopic cholecystectomy within 6 to 8 weeks: A retrospective study. Turk J Surg 2019; 35 (3): 178-184

Corresponding Author Bahtiyar Muhammedoğlu E-mail: baha197647@gmail.com

Received: 31.05 .2018

Accepted: 06.06.2018

Available Online Date: 31.05 .2019

o Copyright 2019 by Turkish Surgical Society Available online at www.turkjsurg.com

DOI: $10.5578 /$ turkjsurg.4204

\section{INTRODUCTION}

Obstructive jaundice is one of the earliest symptoms of hepatobiliary dysfunction. Patients with obstructive jaundice are referred as outpatients or by ambulance to facilities providing endoscopic retrograde cholangiopancreatography (ERCP). ERCP is performed only in selected specialized centers because it is an invasive procedure that involves risks and requires teamwork, expertise and close monitoring. About $60-80 \%$ of patients with gallstones are asymptomatic. Scientific studies have shown that clinical manifestations develop in 1-2\% of patients with silent gallstones each year (1). As reported in the literature, the majority of common bile duct (CBD) calculi originate from the gallbladder and migrate to the bile duct secondarily. The prevalence of choledocholithiasis varies between 10 to $18 \%$ in patients undergoing cholecystectomy for symptomatic gallstones, and in $25 \%$ of the cases, choledocholithiasis may be detected intraoperatively. The current gold standard method is laparoscopic cholecystectomy (LC) which may be performed with or without intraoperative cholangiography (IOC). While about one-third of patients with choledocholithiasis will spontaneously clear the CBD within 6 weeks, severe adverse events of untreated CBD stones such as cholangitis and pancreatitis may develop in the remaining patients. It is therefore generally recommended to detect and treat choledocholithiasis. No single method or algorithm has been shown to be superior to others when treating the obstructing complications of calculous bil- 
iary disease including choledocholithiasis, cholangitis and acute biliary pancreatitis (2).

In recent years, studies on single-stage ERCP and LC have been published in the literature. In our clinic, the single-stage approach is performed during the same surgical session for the treatment of selected patients presenting with choledocholithiasis. The ability to perform ERCP and surgical treatment in the same unit allows us to eliminate organizational problems. Generally, our approach to patients with obstructive jaundice involves single-stage ERCP and LC, ERCP followed by surgery within 4-6 weeks and in the case of difficult stones or failed ERCP, laparoscopic or conventional cholecystectomy. Surgically, these procedures are performed with the following sequence: choledochotomy, IOC, stone removal followed by T-tube placement or choledochoduodenostomy.

Our paper "Approach to patients with obstructive jaundice: Single-stage ERCP and laparoscopic cholecystectomy" was presented as an oral presentation at $14^{\text {th }}$ National Hepato-gastroenterology Congress in April, 2017.

\section{MATERIAL and METHODS}

Of the 350 patients undergoing ERCP between 01.01.2015 and 31.12.2016, 31 patients were assigned to Group A to undergo single-stage ERCP and $L C$ and 25 patients were assigned to Group B to undergo two-stage ERCP followed by LC within 6-8 weeks (Table 1). Eligibility criteria included ERCP duration, the difficulty of the procedure, bile duct stones as demonstrated by imaging methods, no contraindications for LC and no suspected malignancy. Patients assigned to the single-stage treatment first underwent ERCP procedure in the operating room. After ERCP, patient's position was changed and LC was performed under standard conditions. In the two-stage approach, LC was performed within 6-8 weeks. The aim was to compare the study groups with respect to the frequency of imaging, duration of anesthesia and length of stay. Our hospital does not have an institutional ethics committee. Thus, the current research was conducted in accordance with the principles of the World Medical Association Declaration of Helsinki "Ethical Principles for Medical Research Involving Human Subjects".

Table 1. Surgical rates of open and laparoscopic cholecystectomy

\begin{tabular}{|l|l|c|c|}
\hline \multicolumn{2}{|c|}{} & Number & $\%$ \\
\hline \multirow{3}{*}{ Group } & Group 1 & 31 & 55.4 \\
\cline { 2 - 4 } & Group 2 & 25 & 44.6 \\
\hline \multirow{3}{*}{ Surgery } & Open & 7 & 12.5 \\
\cline { 2 - 4 } & LC & 49 & 87.5 \\
\hline \multirow{3}{*}{ Gender } & Male & 21 & 37.5 \\
\cline { 2 - 4 } & Female & 35 & 62.5 \\
\hline \multicolumn{2}{|l|}{ LC: Laparoscopic cholecystectomy. } \\
\hline
\end{tabular}

\section{Statistical Analyses}

The normality of distribution of continuous variables was tested by Shapiro-Wilk test. Mann-Whitney $U$ test was used for the comparison of two independent groups of variables with a non-normal distribution and Chi-square test was used to assess the relation between categorical variables. Statistical analyses were performed using IBM SPSS Statistics for Windows, Version 24.0 and a p value less than 0.05 was considered statistically significant.

\section{RESULTS}

No cases of morbidity or mortality occurred in any groups. IOC was not needed at the time of LC in two-stage Group B patients. Two patients from Group B awaiting LC presented to the emergency room with biliary episodes within 6-8 weeks after ERCP and LC was performed following preliminary arrangements.

The frequency of imaging methods was assessed for both groups before and after ERCP (Table 2). On average, imaging methods were used 3.9 \pm 3.07 times in our Group A series after single-stage procedure and significantly more frequently (5.92 \pm 2.55 times) in Group B ( $<<0.001)$. Thus, the frequency of imaging was lower in our Group A series. Successful cannulation was achieved in 95\% of two-stage Group B patients and in 100\% of one-stage Group A patients; the greater success rate in Group A was related to the fact that patients with failed cannulation were not included in this group. One case of moderate pancreatitis and one case of mild pancreatitis as diagnosed by Atlanta classification occurred in Group B patients. Patients responded well to the medical therapy and were discharged with full recovery. The average length of stay was $8.03 \pm 4.97$ days in our Group A series and significantly longer (9.92 \pm 4.05 days) in Group B series ( $p<$ 0.026) (Table 2). Total duration of anesthesia did not differ statistically significantly between the study groups (154.06 \pm 53.76 min in our Group A series and 167.04 \pm 75.17 min in our Group B series). GGT values were significantly greater in Group A patients (377.78 \pm 306.69$)$ versus Group B (107.95 $\pm 107.64 \mathrm{U} / \mathrm{L}$ (p>0.001). A marked reduction was noted in GGT values following surgery and ERCP (Table 2). Preoperative total bilirubin was significantly elevated in our Group A series (2.56 $\pm 2.25 \mathrm{U} / \mathrm{L})$ compared to Group B series (1.39 $\pm 1.84 \mathrm{U} / \mathrm{L} ; \mathrm{p}>0.010)$. Bilirubin values returned to normal at postoperative day 3 in both groups. Amylase values were comparable between both groups (Table 3).

\section{DISCUSSION}

Study population consisted mainly of female patients (62.5\%) with a smaller percentage of male patients (37.5\%). $87.5 \%$ of the patients was treated with LC and $12.5 \%$ with open conventional cholecystectomy (Table 1).

Currently, the management of obstructive jaundice remains an ongoing topic of debate in the literature. Today, single-session ERCP and LC is a safe and feasible method performed on the basis of studies cited in the literature. Aside from technical ex- 
Table 2. Demographic characteristics of the study population

\begin{tabular}{|l|c|c|c|}
\hline Variables & $\begin{array}{c}\text { Group 1 } \\
(\mathbf{n = 3 1 )}\end{array}$ & $\begin{array}{c}\text { Group 2 } \\
\text { (n= 25) }\end{array}$ & P \\
\hline Age* & $61.29 \pm 19.89$ & $53.6 \pm 18.11$ & 0.140 \\
\hline Gender Female & $14(45.2)$ & $7(28.0)$ & $18(72.0)$ \\
\hline Male & $17(54.8)$ & $9.92 \pm 4.05$ & $0.026^{* *}$ \\
\hline Length of hospital stay ${ }^{*}$ & $8.03 \pm 4.97$ & $167.04 \pm 75.17$ & 0.748 \\
\hline Total duration of anesthesia & $154.06 \pm 53.76$ & $5.92 \pm 2.55$ & $0.001^{* *}$ \\
\hline Frequency of imaging & $3.9 \pm 3.07$ & $65.05 \pm 88.18$ & $0.005^{* *}$ \\
\hline Alanine aminotransferase (U/L)POD 0 & $122.66 \pm 100.04$ & $73.25 \pm 102.12$ & $0.017^{* *}$ \\
\hline Alanine aminotransferase (U/L)POD1 & $101.19 \pm 75.47$ & $54.12 \pm 79.91$ & $0.008^{* *}$ \\
\hline Alanine aminotransferase (U/L) POD3 & $74.9 \pm 54.01$ & $58.75 \pm 63.18$ & $0.029^{* *}$ \\
\hline Aspartate aminotransferase (U/L)POD 0 & $81.86 \pm 60.76$ & $55.63 \pm 47.19$ & $0.038^{* *}$ \\
\hline Aspartate aminotransferase (U/L)POD 1 & $74.58 \pm 53.4$ & $37.64 \pm 28.56$ & $0.024^{* *}$ \\
\hline Aspartate aminotransferase (U/L)POD 3 & $48.26 \pm 26.59$ & $107.95 \pm 107.64$ & $0.001^{* *}$ \\
\hline Gamma-glutamyl-transferasePOD O U/L & $377.78 \pm 306.69$ & $83.14 \pm 89.89$ & $0.001^{* *}$ \\
\hline Gamma-glutamyl-transferasePOD 1 U/L & $318.05 \pm 260.92$ & $93.4 \pm 116.36$ & $0.001^{* *}$ \\
\hline Gamma-glutamyl-transferasePOD 3 U/L & $246.07 \pm 203.9$ & & \\
\hline * Mean \pm Std. deviation. ${ }^{* *}$ Significant at 0.05 level. ${ }^{*} \mathrm{n}(\%)$. & & & \\
\hline POD: Post-operative day. & & & \\
\hline
\end{tabular}

Table 3. Clinical laboratory test results by study groups

\begin{tabular}{|c|c|c|c|}
\hline Variables & $\begin{array}{c}\text { Group } 1 \\
(n=31)\end{array}$ & $\begin{array}{c}\text { Group } 2 \\
(n=25)\end{array}$ & $p$ \\
\hline Creatinine POD 0 mg/dL & $0.86 \pm 0.29$ & $0.75 \pm 0.24$ & 0.220 \\
\hline Amylase (U/L) & $87.44 \pm 99.32$ & $82.34 \pm 99.19$ & 0.798 \\
\hline WBC count $\left(10^{9}\right)$ POD0/L) & $9.48 \pm 4.72$ & $9.08 \pm 4.29$ & 0.876 \\
\hline WBC count $\left(10^{9}\right)$ POD3 & $10.98 \pm 4.15$ & $9.58 \pm 4.27$ & 0.245 \\
\hline Bilirubin total POD 0 (mg/dL) & $2.56 \pm 2.25$ & $1.39 \pm 1.84$ & $0.010^{* *}$ \\
\hline Bilirubin, total POD 1 (mg/dL) & $1.84 \pm 1.27$ & $1.33 \pm 1.08$ & 0.090 \\
\hline Bilirubin, total POD $2(\mathrm{mg} / \mathrm{dL})$ & $1.47 \pm 1.3$ & $0.98 \pm 0.77$ & 0.185 \\
\hline Bilirubin total POD 3 (mg/dL) & $1.38 \pm 1.3$ & $0.8 \pm 0.65$ & $0.034^{* *}$ \\
\hline Direct POD 0 (mg/dL) (mg/dL) & $1.8 \pm 1.89$ & $0.67 \pm 1.07$ & $0.003^{* *}$ \\
\hline Bilirubin, direct POD 1 (mg/dL) & $1.15 \pm 0.99$ & $0.64 \pm 0.69$ & 0.066 \\
\hline Bilirubin, direct POD $2(\mathrm{mg} / \mathrm{dL})$ & $1.03 \pm 1.18$ & $0.44 \pm 0.4$ & $0.028^{* *}$ \\
\hline Bilirubin, direct POD3 (mg/dL) & $0.76 \pm 0.71$ & $0.4 \pm 0.42$ & $0.008^{* *}$ \\
\hline
\end{tabular}

pertise, the procedural success depends on the papillary size, tortuosity, stenosis or abnormal papilla position. When ERCP is performed as indicated, complications can be reduced significantly. The use of conventional imaging methods and identification of the type of icterus are important for the management of patients with obstructive jaundice.
In patients discharged home without operation after acute calculous cholecystitis (ACC), the probability of a gallstone-related events by 6 weeks, 12 weeks and 1 year is 14\%, 19\% and 29\%, respectively. Recurrent symptoms involve biliary colic in $70 \%$, whereas biliary tract obstruction occurs in $24 \%$ and pancreatitis in $6 \%$ of the patients. Despite the frequency of ACC, significant 
controversy remains regarding the diagnosis and management of ACC. The 2007 and 2013 Tokyo guidelines (TG) attempted to establish objective parameters for the diagnosis of ACC (3).

Be et al. state that although LC and therapeutic ERCP have revolutionized the management of cholelithiasis and CBD stones, the use of these modalities as a single-stage procedure remains controversial and conclude in their study that single-stage LC/ ERCP provides efficient therapy for CBD stones and might be beneficial in select patients who may not tolerate a second anesthetic procedure (4).

In 2007, the Tokyo Guidelines for the management of acute cholangitis and cholecystitis (TG07) were first published in the Journal of Hepato-Biliary-Pancreatic Surgery. The Tokyo Guidelines Revision Committee (TGRC) was set up in June 2010 because of the detection of low diagnostic sensitivity of TG07 for acute cholangitis. The TGRC held meetings a total of 35 times. The updated Tokyo Guidelines (TG13) have a superior diagnostic capability compared to TG07 due to higher sensitivity (87.6\%) and specificity (77.7\%). Ultrasonographic Murphy's sign has a high specificity but low sensitivity (5).

As recommended by the TG13 for the management of acute cholecystitis, laparoscopic cholecystectomy is the first-line treatment in patients with Grade I (mild) acute cholecystitis. In patients with Grade II (moderate) acute cholecystitis, delayed/ elective laparoscopic cholecystectomy after initial medical treatment is the first-line treatment. In non-responders to initial medical treatment, gallbladder drainage should be considered. In patients with Grade III (severe) acute cholecystitis and organ failure, appropriate organ support in addition to initial medical treatment is necessary. Urgent or early gallbladder drainage is recommended. Cholecystectomy can be performed after improvement of the acute inflammatory process (6).

There are some studies in the literature on the timing of treatment recommended by the TG13. V Amirthalingam et al. reported that the Tokyo Guidelines 2013 may be too restrictive and in patients with moderate and severe acute cholecystitis, the severity grading of $A C$ is not the sole determinant of early $L C$ and patient comorbidity also has an impact on clinical decisions (7).

Discussions are ongoing about the most appropriate time and the best method to remove the bile duct calculi. Intraoperative endoscopic retrograde cholangiopancreatography (IO-ERCP) should be considered as an alternative method for this purpose (8).

Two-stage approach including ERCP followed by LC within a couple of weeks is the current management of choledocholithiasis. Performing ERCP and LC in a single-session has not been fully established in major guidelines. Although relevant literature is scarce, one of the main reasons leading to the adoption of two-stage approaches is the fact that these are performed by two specialists from separate medical fields. Potential or actual organizational problems may have avoided further advances in single-session ERCP and LC. Also, restrictive nature of the current guidelines for the management of acute cholecystitis is another reason.

Maris Jones et al. have been performing one-step procedures since 1997. The results of their work were presented in 1998 at the sixth World Congress of Endoscopic Surgery, and at the American Society of Gastrointestinal Surgeons (SAGES) annual conference in 2010.

Hyperbilirubinemia and cholestasis are two closely related but distinct entities. While hyperbilirubinemia refers solely to elevated bilirubin, cholestasis manifests itself with increased GGT and ALP levels. Also, a range of causative factors overlap in the development of hepatocellular and cholestatic jaundice (9). For the management of patients with jaundice, each case should be managed with utmost care in order to determine the pathogenesis of the jaundice and employ appropriate therapeutic options.

In the present study, the common bile duct was cannulated using the standard technique in patients included in the study group. Precut technique was used for CBD cannulation in two patients in whom cannulation was particularly difficult. For the Group A patients undergoing single-stage procedure, change from left lateral position to supine position was easily done immediately after ERCP before initiation of LC. Single-stage ERCP/ LC was carried out as described by the relevant literature. Our main advantage was the fact that the same surgeon performed both procedures. This approach has considerable advantages in the management of patients with obstructive jaundice by avoiding delays and organizational problems since the same surgeon is responsible for the whole treatment and follow-up of the patient, which also leads to successful patient management and monitoring.

Pencev et al. have reported that ERCP can be safely done within the first 24 hours of laparoscopic cholecystectomy but delays in removal of CBD stones may lead to complications and malignancy should be excluded in patients with persistent jaundice (10). In the present study, ERCP was repeated in one Group B patient because of persistent jaundice who was later diagnosed with primary sclerosing cholangitis.

In the study by Kimura et al., the proportion of acute cholangitis and cholecystitis after ERCP was $0.5-2.4 \%$ for cholangitis and 0.2-1.0\% for acute cholecystitis (3). In our study, corresponding figures were $0.57 \%$ and $0.86 \%$ for the total number of patients undergoing ERCP, which are consistent with the literature. First ERCP and then LC were performed for the single-stage procedure in our Group A patients. Cholecystectomy operation might be relatively difficult for gas accumulation in the bowel when ERCP is prolonged. In some studies have noted in their retrospective review that ERCP can be performed first safely with 
only a slight degree of small bowel dilation at the time of LC (11). LC was relatively difficult in patients with a prolonged ERCP time. This results from bowel distension after air insufflation. In order to avoid this, air was adequately aspirated while removing the duodenoscope after ERCP. However, it is not often possible to aspirate all the air in the intestines. We also employed rectal tube in the case of excessive bowel distension. LC was safely done after ERCP. Jones et al. have stated that one-step procedure has a bright future for the treatment of choledocholithiasis and do not advocate the routine use of intraoperative ERCP in uncomplicated laparoscopic or open cholecystectomies; however they consider that one-step procedure may be highly advantageous in certain cases (2). None of the patients in single-stage Group A presented with biliary episodes or complaints after discharge.

IOC was not needed at the time of LC in two-stage Group B patients. Two patients from Group B awaiting LC presented to the emergency room with biliary episodes within 6-8 weeks after ERCP and LC was performed following preliminary arrangements. The frequency of imaging methods was assessed for both groups before and after ERCP (Table 2). On average, imaging methods were used $3.9 \pm 3.07$ times in our Group A series after single-stage procedure and significantly more frequently (5.92 \pm 2.55 times) in Group B ( $p<0.001)$. Thus, the frequency of imaging was lower in our Group A series.

Sahoo et al. have randomized 83 patients with cholecystocholedocholithiasis into two groups (12). In group A, 41 patients underwent first ERCP and then $L C$ and in group B, 42 patients underwent $\mathrm{LC}$ and intraoperative cholangiography and when choledocholithiasis was confirmed, these patients had ERCP by laparoendoscopic rendez-vous technique. Successful cannulation was achieved in 33 (80.5\%) cases in group A and 39 cases (93\%) in group B. In the same study, severe pancreatitis developed in 12\% of group A patients and in none of the patients in group B. In our study, successful cannulation was achieved in 95\% of two-stage Group B patients and in 100\% of one-stage Group A patients; the greater success rate in Group A was related to the fact that patients with failed cannulation were not included in this group. One case of moderate pancreatitis and one case of mild pancreatitis as diagnosed by Atlanta classification occurred in Group B patients. Patients responded well to the medical therapy and were discharged with full recovery.

Mallick et al. have shown that ERCP/ LC is a safe and effective option when performed in a single-session at a tertiary care center and is associated with a reduced length of hospitalization (11). The average length of stay was $8.03 \pm 4.97$ days in our Group A series and significantly longer ( $9.92 \pm 4.05$ days) in Group B series $(p<0.026)$ (Table 2). However, the length of stay (in days) was calculated as the time from presentation to hospital until discharge and not the time elapsed after the procedure. This period included the time spent for ultrasonography (USG), magnetic resonance cholangiopancreatography (MRCP) and preoperative preparations. This explains the longer length of stay (LOS) in our study compared to LOS cited in the literature since all steps of patient management were included when calculating the length of hospital stay. Another reason for prolonged length of stay in our study was the inclusion of time spent for diagnosis and preparation of the patients with obstructive jaundice after taking over their management from consulting physicians. Although our institution is a secondary-care hospital, treatment of patients with obstructive jaundice is provided effectively and safely. An important factor that facilitates the organizational steps is related to the fact that the same surgeon performs both procedures for the patient.

In their study, Sahoo et al. have advocated that intraoperative endoscopic retrograde cholangiopancreatography (IO-ERCP) is an effective method that can be safely performed in routine clinical setting and is associated with a lower postoperative risk of pancreatitis and shorter hospital stay in patients with choledocholithiasis detected with IOC during LC (12). None of the patients in our single-stage Group A developed pancreatitis following ERCP or complications related to $L C$ and single-stage was performed safely. Interestingly, all of the patients (in both groups) meeting the eligibility criteria expressed their wish to be treated with the single-stage procedure before signing the informed consent. Strict patient selection criteria were employed in our study and patients with prolonged ERCP and those who did not meet aforementioned eligibility criteria were excluded from Group A.

In their study Bansal et al. have randomized 168 patients (84 to the single-stage procedure and 84 to the two-stage procedure) and concluded that single- and two-stage treatments had similar success and complication rates but the single-stage strategy was better in terms of shorter hospital stay, reduced need for additional procedures and cost effectiveness (13). In the present study, while comparable results were obtained in both groups, previously mentioned advantages were achieved in our Group A.

Laparoscopic common bile duct exploration provides an alternative therapeutic approach that is safer and more reliable, allows for earlier recovery, and provides a cost-effective treatment of common bile duct stones (14). ERCP is an established procedure for the management of bile duct stones before and after laparoscopic cholecystectomy but laparoscopic choledochal exploration (LCE) is still evolving and experience is currently limited with very few institutions. Given the anatomical variations of the cystic duct opening into the bile duct, we believe that LCE is not appropriate for the management of choledocholithiasis. Thus, we did not perform LCE in our patients.

The single-stage LC/ERCP provides an effective treatment for cholelithiasis and choledocholithiasis and might be beneficial in select patients who may not tolerate a second anesthetic 
procedure (4). Mean age of our patients was $61.29 \pm 19.89$ years and completion of the procedures under the same anesthesia provides improved patient satisfaction and is advantageous for elderly patients who cannot tolerate a second anesthetic procedure. Total duration of anesthesia did not differ statistically significantly between the study groups (154.06 $\pm 53.76 \mathrm{~min}$ in our Group A series and $167.04 \pm 75.17 \mathrm{~min}$ in our Group B series). GGT values were significantly greater in Group A patients (377.78 \pm 306.69) versus Group B (107.95 \pm 107.64 U/L ( $p>0.001)$. A marked reduction was noted in GGT values following surgery and ERCP (Table 2). Preoperative total bilirubin was significantly elevated in our Group A series (2.56 $\pm 2.25 \mathrm{U} / \mathrm{L})$ compared to Group B series $(1.39 \pm 1.84 \mathrm{U} / \mathrm{L} ; \mathrm{p}>$ $0.010)$. Bilirubin values returned to normal at postoperative day 3 in both groups. Amylase values were comparable between both groups (Table 3).

Although early and delayed CCY equally reduce the risk of subsequent recurrent biliary events, patients are at 10-fold higher risk of a recurrent biliary event while waiting for a delayed cholecystectomy compared to patients who underwent early cholecystectomy (15). In our study, recurrent biliary episodes were not detected in patients who underwent ERCP and LC at the same session.

In a randomized study with 372 patients, Nathanson et al. have suggested that $66 \%$ of CBD stones can be extracted using trans-cystic duct clearance and advocated that this method is a good choice for patients after Billroth II gastrectomy, failed ERCP access or where long delays would occur for patient transfer to other locations for the ERCP (16). In the present study, we considered that trans-cystic duct clearance would be inappropriate for our patients and avoided this strategy.

Baillie et al. have reported that same-day laparoscopic cholecystectomy following ERCP for choledocholithiasis may confer additional benefits for patients with major comorbidities (17) They propose the use of $\mathrm{CO}_{2}$ insufflation instead of air insufflation to overcome problems associated with bowel distension. In our single-stage group, ERCP procedure was conducted using air insufflation and the air trapped in the bowel did not pose any problem during LC. However, due to safety reasons, we preferred the open technique for port access for LC. Despite safe performance of LC after ERCP, air can still be present inside the intestinal loops.

Bansal et al. have compared the outcomes of primary laparoscopic CBD exploration (LCBDE) and secondary LCBDE after failed ERCP in patients with choledocholithiasis and found that mean operative time, the degree of difficulty, length of hospital stay and cost of procedure were significantly reduced in the group undergoing primary LCBDE for difficult stones (18). In our study, one patient with a difficult stone underwent LC following failed ERCP and choledochotomy and the stone was extracted using an endoscopicstoneretrievalbasket.
Limitations of our study include its retrospective design and the small sample size.

\section{CONCLUSION}

In conclusion, single-stage ERCP/laparoscopic cholecystectomy is associated with shorter hospital stay and lower frequency of imaging and can be safely used in selected cases. Additionally, none of the patients undergoing single-stage procedure was admitted to the emergency room for pancreatitis or recurrent biliary episodes. Single-stage procedure can be safely used in select patients with obstructive jaundice who may not tolerate a second anesthetic procedure.

Ethics Committee Approval: Ethics committee approval was not obtained because the study was a retrospective study.

Peer-review: Externally peer-reviewed.

Author Contributions: Consept - B.M.; Design - B.M.; Supervision - B.M.; Resource - B.M.; Materials - B.M.; Data Collection and/or Processing - B.M.; Analysis and Interpretation - B.M.; Literature Search - B.M.; Writing Manuscript - B.M.; Critical Reviews - B.M..

Conflict of Interest: No conflict of interest was declared by the authors.

with this study.

Financial Disclosure: The authors declared that this study has received no financial support.

\section{REFERENCES}

1. Callery MP, Beard RE, Stewart L. Blumgart's Surgery of the Liver, Biliary Tract and Pancreas, Chapter 37, 623-632.e3

2. Jones M, Johnson M, Samourjian E, Slauch K, Ozobia N. ERCP and laparoscopic cholecystectomy in a combined (one-step) procedure: a random comparison to the standard (two-step) procedure. Surg Endosc 2013; 27: 1907-12. [CrossRef]

3. Kimura Y, Takada T, Strasberg SM, Pitt HA, Gouma DJ, Garden OJ, et al. TG13 Current terminology, etiology, and epidemiology of acute cholangitis and cholecystitis. J Hepatobiliary Pancreat Sci 2013; 20: 8-23. [CrossRef]

4. Wright BE, Freeman ML, Cumming JK, Quickel RR, Mandal AK. Current management of common bile ductstones: Is there a role for laparoscopic cholecystectomy and intraoperative endoscopic retrograde cholangiopancreatography as a single-stage procedure? Surgery 2002; 132: 729-35; discussion 735-7. [CrossRef]

5. Takada T, Strasberg SM, Solomkin JS, Pitt HA Gomi H, Yoshida M, et al. TG13: Updated Tokyo Guidelines forthe management of acute cholangitis and cholecystitis J Hepatobiliary Pancreat Sci 2013; 20: 1-7. [CrossRef]

6. Miura F, Takada T, Strasberg SM, Solomkin JS, Pitt HA, Gouma DJ, et al.TG13 flowchart for the management of acute cholangitis and cholecystitis. J Hepatobiliary Pancreat Sci 2013; 20: 47-54. [CrossRef]

7. Amirthalingam V, Low JK, Woon W, Shelat V. Tokyo Guidelines 2013 may be too restrictive and patients with moderate and severe acute cholecystitis can be managed by early cholecystectomy too. Surg Endosc 2017; 31: 2892-900. [CrossRef]

8. Enochsson L, Lindberg B, Swahn F, Arnelo U. Intraoperative endoscopic retrograde cholangiopancreatography (ERCP) to remove common bile duct stones during routine laparoscopic cholecystectomy does not prolong hospitalization: a 2-year experience. Surg Endosc 2004; 18: 367-71. [CrossRef] 
9. Özaslan E, Bayraktar Y. Approach to jaundiced patient and sample cases. Current Gastroenterology 1998; 85-117.

10. Pencev D, Brady PG, Pinkas H, Boulay J. The role of ERCP in patient safter laparoscopic cholecystectomy. Am J Gastroenterol 1994; 89: 1523-7.

11. Mallick R, Rank K, Ronstrom C, Amateau SK, Arain M, Attam R, et al. Single-session laparoscopic cholecystectomy and ERCP: a valid option forthe management of choledocholithiasis. Gastrointest Endosc 2016: 84: 639-45. [CrossRef]

12. Sahoo MR, Kumar AT, Patnaik A. Randomised study on single stage laparo-endoscopic rendezvous (intra-operative ERCP) procedure versus two stage approach (Pre-operative ERCP followed by laparoscopic cholecystectomy) for the management of cholelithiasis with choledocholithiasis. J Minim Access Surg 2014; 10: 139-43. [CrossRef]

13. Bansal VK, Misra MC, Rajan K, Kilambi R, Kumar S, Krishna A, et al. Single-stage laparoscopic common bile duct exploration and cholecystectomy versus two-stage endoscopic stone extraction followed by laparoscopic cholecystectomy for patients with concomitant gallbladder stones and common bile duct stones: a randomized controlled trial. Surg Endosc 2014; 28: 875-85. [CrossRef]
14. Li KY, Shi CX, Tang KL, Huang JZ, Zhang DL. Advantages of laparoscopic common bile duct exploration in common bile duct stones. Wien Klin Wochenschr 2018; 130: 100-4. [CrossRef]

15. Huang RJ, Barakat MT, Girotra M, Banerjee S. Practice patterns for cholecystectomy following endoscopic retrograde cholangio-pancreatography for patients with choledocholithiasis. Gastroenterology 2017.

16. Nathanson LK, O'Rourke NA, Martin IJ, Fielding GA, Cowen AE, Roberts $R K$, et al. Postoperative ERCP versus laparoscopic choledochotomyfor clearance of selected bile duct calculi: a randomized trial. Ann Surg 2005; 242: 188-92. [CrossRef]

17. Baillie J, Testoni PA. Same-day laparoscopic cholecystectomy and ERCP for choledocholithiasis. Gastrointest Endosc 2016; 84: 646-8. [CrossRef]

18. BansalVK, Krishna A, Rajan K, Prajapati O, Kumar S, Rajeshwari S, et al. Outcomes of laparoscopic common bile duct exploration after failed endoscopic retrograde cholangiopancreatography in patients with concomitant gall stones and common bile duct stones: a prospective study. J Laparoendosc Adv Surg Tech A 2016; 26: 985-91. [CrossRef]

\section{ORIJINAL ÇALIŞMA-ÖZET}

Turk J Surg 2019; 35 (3): 178-184

\section{Eş zamanlı ERCP ve laparoskopik kolesistektomiye karşı çift aşamalı ERCP ve 6-8 hafta takiben laparoskopik kolesistektomi: retrospektif çalışma}

Bahtiyar Muhammedoğlu ${ }^{1}$

${ }^{1}$ Necip Fazıl Şehir Hastanesi, Genel Cerrahi Kliniği, Kahramanmaraş, Türkiye

\section{ÖZET}

Giriş ve Amaç: Tıkanma sarılığı hepatobiliyer sistem hastalıklarının en erken ortaya çıkan semptomlarından birisidir. Tıkanma sarılığı olan hastaların bir kısmı poliklinikten, diğer kısmı 112 ile veya ayaktan sevkle endoskopik retrograd kolanjiyopankreatografi (ERCP) yapılan merkezlere başvurmaktadır. ERCP işleminin seçilmiş merkezlerde yapılıyor olması riskli bir invaziv işlem olmasının yanında güncel yönetim, tecrübe ve yakın takip gerektiren bir işlem olmasından kaynaklanmaktadır. Gruplar single seans yapılan grup A ve ERCP takiben 6 hafta sonra laparoskopik kolesistektomi (LK) yapılan grup B olarak belirlendi. Gruplar hasta memnuniyeti, KCFT değerlerinin normale dönüşümü, toplam anestezi süresi ve görüntüleme yöntemlerinin kulanım sıklığı açısından değerlendirildi.

Gereç ve Yöntem: 01.01.2015-31.12.2016 tarihleri arasında ERCP yapılan 350 olgu arasından 31 hasta tek aşamalı ERCP ve LK için belirlenmiş uygun kriterlere göre ve 25 hasta çift aşamalı ameliyat için seçildi. Tek aşamalı olgular grup A olarak, çift aşamalı olgular grup B olarak belirlendi. Seçme kriteri olarak ERCP süresi, işlem zorluğu, görüntüleme yöntemi ile kanıtlanmış safra yolu taşları, malignite şüphesi ve bulgusunun olmaması, geçirmiş batın ameliyatı olmaması ve LK'ye kontrendike durumların olmaması olarak belirlendi.

Bulgular: Çalışmamızdaki gruba dahil edilen grupta papilla standart teknik ile kanülize edildi. Papilla kanülasyonu zor olan 2 hastada precut tekniği kullanarak koledok kanülize edildi. Serimizde ERCP işlemi sonrası laparoskopik kısmı başlanmadan önce hasta pozisyonu kolayca değiştirilebildi. Çalışmamızda eş zamanlı işlemler önce ERCP daha sonra LK şeklinde uygulandı.Tek aşamalı LK/ERCP, kolelitiazis ve koledokolitiazis için etkili tedavi sağlar ve ikinci bir anestezi prosedürüne tolerans göstermeyen seçilmiş hastalarda faydalı olabilir. Ortanca yaş grubu 61,29 $\pm 19,89$ olup tek anestezi ile tedavisinin tamamlanması sadece hasta memnuniyeti için değil ikinci bir anestezi işlemine tolerans göstermeyen hastalar için avantajıdır.

Sonuç: Sonuç olarak tek aşamalı ERCP ve LK hastanede kalış, daha az görüntüleme yöntemlerinin kullanım sıklığı ve toplam anestezi süresi açısından avantajlı olup seçilmiş olgularda güvenli şekilde kullanılabileceği kaydedilmiştir. Aynı zamanda tek aşamalı işlem sonrası pankreatit insidansı düşük bulunmuştur. Tek aşamalı ERCP takiben LK'nin klavuz haline gelmesi için gelecekte çok sayıda çalışmalara ihtiyaç vardır.

Anahtar Kelimeler: Endoskopik retrograd kolanjiyopankreatografi, laparoskopik kolesistektomi, manyetik rezonans kolanjiyopankreatografi, ultrasonografi

Doi: $10.5578 /$ turkjsurg.4204 